American Journal of Environmental Sciences 8 (3): 334-344, 2012

ISSN 1553-345X

(C) 2012 Science Publications

\title{
The Diatom Stratigraphy of Rawapening Lake, Implying Eutrophication History
}

\author{
${ }^{1}$ Tri Retnaningsih Soeprobowati, \\ ${ }^{2}$ Suwarno Hadisusanto, ${ }^{3}$ Peter Gell and ${ }^{4}$ Atun Zawadski \\ ${ }^{1}$ Department of Biology, The University of Diponegoro, Semarang, Indonesia \\ ${ }^{2}$ Faculty of Biology, Gadjah Mada University, Yogyakarta, Indonesia \\ ${ }^{3}$ Centre for Environmental Management, School of Science, IT and Engineering, \\ The University of Ballarat, Ballarat, Australia \\ ${ }^{4}$ Australian Nuclear for Science and Technology Organization, Sydney, Australia
}

\begin{abstract}
Problem statement: The use of diatoms to reconstruct past ecological conditions in lakes is well established. Diatoms are microscopic algae that forms siliceous frustules which allow them to preserve well in sediments. Rawapening Lake is one of 15 Indonesian lakes identified as 2010-2014 National Priority Lakes. Naturally, Rawapening is a tectono-volcanic lake. In the early 1900s, the sole outlet of the lake, Tuntang River, was impounded for hydroelectricity, irrigation and fisheries. Since then Rawapening had become a semi natural lake. The main problem of Rawapening Lake is blooming of water hyacinth that reduce lake function. This research was conducted in order to reconstruct the nutrient history of Rawapening Lake, Java. Approach: Sediment samples were taken from four sites and were sliced every $0.5 \mathrm{~cm}$ for diatom analysis and bulked across $2-5 \mathrm{~cm}$ for ${ }^{210} \mathrm{~Pb}$ radiometric dating of sediment. Diatom analysis consisted of three steps: the digestion process to separate the diatoms from the sediment; preparation and mounting of diatom residues onto slides and identification-enumeration. Results: The diatom-inferred condition of Rawapening Lake may be divided into four phases represented by zone 1 (1967-1974), zone 2 (1974-1983), zone 3 (1984-1990) and zone 4 (1990-2008). The predominance of Synedra from 1967 to present indicates that Rawapening Lake has been fresh and meso-eutrophic throughout. Zone 1 is also characterized by Fragilaria capucina Desm, Luticola goeppertiana (Bleisch) Mann, Mayamae atomus (Kutzing) Lange-Bertalot, Navicula radiosa Kutzing, Nitzschia palea (Kutzing) W. Smith and in one site, Tryblionella apiculata Gregory, that reflect eutrophic, but clear waters. An increase in epiphytic Gomphonema spp. in zone 2 marks an increase in aquatic macrophyte plants, perhaps in response to high nutrient levels. This change is followed promptly by an increase in acidophilous Eunotia spp. reflecting high organic production. A transition to a diatom community dominated by planktonic forms occurs c. 1983 . This community was initially dominated by more clear water, oligotrophic species such as Discostella stelligera (Cleve and Grunow) Houk and Klee and Aulacoseira distans (Ehrenberg) Simonsen, but transitions in 1990 to one dominated by A. granulata (Ehrenberg) Simonsen and ultimately Aulacoseira ambigua (Grunow) Simonsen. This is interpreted as a shift to a turbid water phase that has advantaged phytoplankton, at the expense of benthic or epiphytic taxa that require clear water. Conclusion: The dominance of A. granulate (Ehrenberg) Simonsen since the 1990s indicates the lake experienced hypertrophic conditions with $\mathrm{pH}>9$. A high proportion of the taxa in Rawa Pening sediments are not represented in the European data set, so the development of data set of tropical lakes is recommended to provide stronger inferences in local settings.
\end{abstract}

Key words: Eutrophication, Rawapening Lake, nutrient, diatom

\section{INTRODUCTION}

Diatoms are a dominant form of microalgae in all aquatic ecosystems. They contribute $20-25 \%$ of the primary production in many systems and they have an important role in the silica and carbon cycle (Mann, 1999). Different taxa have different levels of tolerance to environmental (water quality) variables, therefore, fossil diatom assemblages preserved in lake sediments reflect past environmental conditions effectively (Dixit 
et al., 2001; Gell et al., 2007; Reid et al., 1995; Reid and Ogen, 2009). In recent years diatom research has focused on the application of sedimentary assemblages to reconstruct past water quality conditions (Smol, 2008).

Rawapening Lake is a tectono-volcanic lake situated in the Central Java, Indonesia, $45 \mathrm{~km}$ to the south of the city of Semarang. It is a circular lake of 2,000 $\mathrm{Ha}$ surface areas situated at $400 \mathrm{mASL}$. It is supplied by flows from 16 stream inlets, many of which are used for domestic water supply for the 17 villages surrounding the lake, or diverted for paddy field development. In the early 1900s its only outlet was impounded to ensure supplies for hydroelectricity development and to mitigate the risk of flooding downstream (GS, 2000).

The lake acts as a sink for pollutants released across the intensively used catchment and within the lake itself. Industrial, urban and agricultural development has increased the loads of fertilizers and metal pollutants to the lake. The development of the steep catchment slopes has resulted in increased turbidity in the inlet streams and increased sediment loads to the lake (EM, 2010). The present poor water quality of the lake precludes its use for water supply. Pesticide uses in paddy fields, the use of pellets to improve fisheries production and the excess fish catches, have further led to a decline in the available fishery.

From the 1930s the lake was invaded by water hyacinth (Eichornia crassipes (Mart.) Solms) and other aquatic invasives, Hydrilla and Salvinia (Goltenboth and Timotius, 1994; UNEP, 1999). Now, over $40 \%$ of the lake is covered with water hyacinth. The degraded state of this lake has drawn the attention of the United Nations Environment Program and Indonesian authorities and there is, within the Indonesian Environmental Regulatory Report Number 32 (2009), a directive to establish management plans for the lake to improve its water quality and amenity. The Bali Agreement of 2009, resulting from the actions of 9 ministries decided that Rawapening is 1 of 15 priority lakes for conservation over 2010-2014.

Research on paleolimnology in Indonesia is very limited (Hehanusa and Haryani, 2009). This research was conducted in order to reconstruct the diatominferred nutrient history of the Rawapening Lake to identify the drivers of eutrophication. The reconstruction of nutrients and habitat changes over time is interpreted in light of the known settlement and lake management history. Abrupt changes in condition coincident with specific events suggest a history of direct impacts on the lake's condition; whereas gradual changes suggest more diffuse and chronic impacts.

\section{MATERIALS AND METHODS}

Field sampling: In 2008 an intensive regime of diatom and water quality sampling was undertaken covering a range of substrates across the Lake. The water quality variables analyzed comprising dissolved oxygen, temperature, conductivity, turbidity and $\mathrm{pH}$. A comprehensive bathymetric study was undertaken on Rawapening Lake in August 2008 (Fig. 1). Echosounding of the lake reveals extensive areas of less than $2 \mathrm{~m}$ depth but three deeper depocentres in the lake's west of up to $18 \mathrm{~m}$ depth. This was used to direct coring activities. At multiple core sites surface sediment samples and water samples were taken from which total nitrogen, total phosphorous, silica, lead, cadmium, chromium and copper were analyzed. The collected sediment cores ranged in length from $29-63 \mathrm{~cm}$. These were sub sampled in fine resolution $(0.5 \mathrm{~cm})$ for diatoms.

Sediment subsamples were prepared following Last and Smol (2001), identified following standard texts (Krammer and Lange-Bertalot, 2010) and by comparison with the reference collections held at Diponegoro University and The University of Ballarat. Counts of a minimum of 300 valves were taken on a subset of samples. The software ERNIE (Juggins, 2001) was used to reconstruct nutrient histories of the lake. As each site had multiple substrate diatom samples, it was possible to reconstruct the changing nature of the aquatic habitat (e.g., lake shallowing; invasion of emergent and floating macrophytes; changing light regime) within Rawapening over recent time, independent of diatom-inferred nutrient changes. The fossil diatom assemblages are presented in the data management and drawing package C2 1.5.1 (Juggins, 2003).

Chronology: The $50 \mathrm{~mm}$ diameter cores taken from Rawapening were unlikely to provide sufficient sediment to allow for gamma analysis each centimeter so samples were bulked across $2-5 \mathrm{~cm}$. Ten subsamples/core, each of 20-30 dry grams, were prepared for gamma spectrometry to derive ${ }^{210} \mathrm{~Pb}$ ages for four cores. Particle size analysis was undertaken largely as a precaution given the site is in a steep catchment with high rainfall. This aids in the choice of age-depth model (CIC or CRS) used to derive sedimentation rates from each core.

Geochronology, based on the changes to the diatom biostratigraphy, especially major shifts in benthic, epiphytic and planktonic forms, enabled a broad chronology to be applied across cores. Subsamples were also taken for analysis of moisture and organic (LOI) content using standard loss-ofweight on drying and ashing methods. 


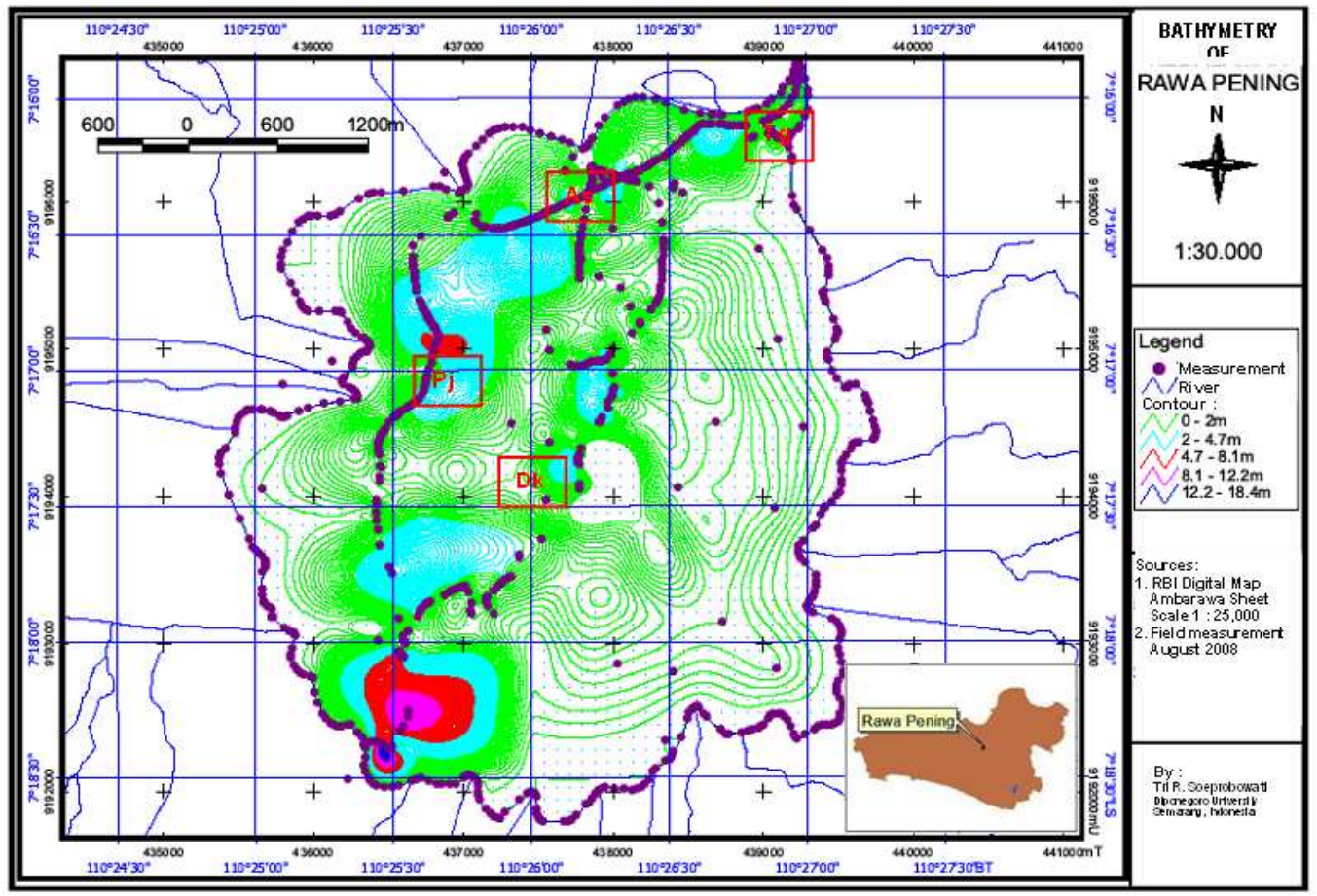

Fig. 1: Bathymetric map of Rawapening Lake and core length. As = Asinan, Tg = Tuntang, Dk = Dangkel and $\mathrm{Pj}=$ Panjang

\section{RESULTS}

Sediment core chronology-Rawapening: Fourteen sediment samples were used to establish the chronology of the $63 \mathrm{~cm}$ long Asinan core. The unsupported ${ }^{210} \mathrm{~Pb}$ activities in the Asinan core exhibit an overall decreasing profile with increasing depth (Fig. 2). The basal sediment samples also showed activity suggesting the profile had not reached background and that the sediments were $<100$ years old. The CRS model at Asinan core provided a mass accumulation rate of $1.26 \pm 0.05 \mathrm{~g} \mathrm{~cm}^{-2} /$ year to $60 \mathrm{~cm}$ depth equating to an age of $41 \pm 1.6$ years (Table 1). The sedimentation rate using the CIC model however, was $1.155 \pm 0.113 \mathrm{~g}$ $\mathrm{cm}^{-2} /$ year, $\left(\mathrm{r}^{2}=0.937\right)$, suggesting an age of $48.6 \pm 4.8$ years at $63 \mathrm{~cm}$. Assuming $0 \mathrm{~cm}$ is equivalent to $2008 \mathrm{AD}$, the sediments at $63 \mathrm{~cm}$ were deposited in 1955-1964 (CIC model) or 1965-1969 (CRS model). The CRS model was used as a basis for the chronology accompanying the diatom stratigraphy graph.

Eleven sediment samples were analyzed to establish the chronology of the Tuntang core. The unsupported ${ }^{210} \mathrm{~Pb}$ activities in this core exhibit an overall decreasing profile with increasing depth (Fig. 3 ), at least as far as $10.5 \mathrm{~cm}$. The unsupported ${ }^{210} \mathrm{~Pb}$ activities below $12.5 \mathrm{~cm}$ are close to being constant. The sediment below $12.5 \mathrm{~cm}$ may all be of the same age (due to rapid deposition); however, diatom changes exist in the stratigraphy, suggesting continual, rather than episodic, accumulation. The CIC model reveals a mass accumulation rate of $0.13 \pm 0.01 \mathrm{~g} / \mathrm{cm}^{2} /$ year $\left(\mathrm{r}^{2}=\right.$ $0.9926)$, allowing an age of 54.1 \pm 7.1 years (1947-1961 AD) for $33.5 \mathrm{~cm}$ depth. The CRS model provides a mass accumulation rate of $0.15 \pm 0.01 \mathrm{~g} / \mathrm{cm}^{2} /$ year and an age of 38.5 \pm 1.9 years $(1968-1971 \mathrm{AD})$ for $10.5 \mathrm{~cm}$ depth (Fig. 3 and Table 2).

The sample sizes processed for Dangkel" s core were very short (Fig. 4 and Table 3).

Only 4 out of 36 samples were analyzed from the Panjang core. This core shows a slightly decreasing activity of unsupported ${ }^{210} \mathrm{~Pb}$ with depth (Fig. 5 and Table 4). Analysis of more samples is required for the deeper part of the core, to ascertain whether the levels of unsupported ${ }^{210} \mathrm{~Pb}$ activity reach background. Despite this, based on the analyses made, the CIC and CRS ${ }^{210} \mathrm{~Pb}$ dating models were used to estimate sediment ages. The CIC model provided a weak result $\left(r^{2}=0.6039\right)$ for a mass accumulation rate of $1.309 \pm 0.01 \mathrm{~g} / \mathrm{cm}^{2} / \mathrm{year}$ with $16-16.5 \mathrm{~cm}$ depth equal to $12.42 \pm 7.11$ years $(1988-2003$ AD). Assuming constant sedimentation this would suggest the $32 \mathrm{~cm}$ core covers $24.54 \pm 7.11$ years or was initially deposited in 1976-1990. The CRS model however, provides a strong relation $\left(\mathrm{y}=0.6889 \mathrm{x}+0.0751, \mathrm{r}^{2}=\right.$ 0.9972 ). From this model the sediments at $16-16.5 \mathrm{~cm}$ date to $10.9 \pm 2.3$ years and so were deposited between 1995 and 1999 AD (Table 4). 
Diatom biostratigraphy of Rawapening Lake: The longest sediment core $(63 \mathrm{~cm})$ was from the Asinan site. The Panjang and Tuntang cores were $36.5 \mathrm{~cm}$ and $35.5 \mathrm{~cm}$ long, respectively, while that at Dangkel was 29 $\mathrm{cm}$. The Asinan core can be divided into four zones based on a cluster analysis of diatom assemblages, whereas Tuntang and Panjang may be divided into 3 zones and Dangkel into 2 zones (Fig. 6-9). This discussion is based principally on the results of the Asinan site, as it yielded the longest core and was well dated, but it is also with reference to the other three cores.

Zone IV (1967-1974): The lowest zone is dominated by Gomphonema parvulum (Kutzing) Kutzing, Luticola goeppertiana (Bleisch) Mann, Luticola mutica (Kutzing) Mann, Mayamaea (syn:Navicula) atomus (Kutzing) Lange-Bertalot, Nitzschia palea (Kutzing) W.Smith and Nitzschia umbonata (Ehrenberg) LangeBertalot. These species are indicators of high nutrient concentrations confirming the enriched status of the Rawapening Lake from the base of this record. Other common taxa include Fragilaria capucina Desm, Gomphonema gracilis Ehr. and Navicula radiosa Kutzing which suggest alkaline conditions; however, the presence of Eunotia pectinalis (Kutzing) Rabenhorst var. undulata (Ralfs) Rabh suggest neutral to slightly acid conditions. Synedra ulna (Nitzsch) Ehrenberg is also a common species that persists to the upper sediments. This assemblage, with low representation of planktonic forms, is evident in the basal zone of the Tuntang core but not Panjang, supporting the dating evidence for the former holding the longest record. While a clear chronology is not available for the Dangkel core, the predominance of Fragilaria capucina Desm suggests it may date to the 1970s. The presence of Tryblionella apiculata (Gregory) as a common taxon is exclusive to this core.
Zone III (1974-1983): Zone 3 in Asinan is marked by declines in several eutrophic indicators and a marked increase in Ulnaria (syn: Synedra) acus (Kutzing) M.Aboel and the emergence of the oligotrophic plankton Discostella stelligera (Cleve and Grunow) Houk and Klee. Here the epiphytes G. parvulum (Kutzing) H.F.va Heurck and Gomphonema. truncatum Ehrenberg increase and $E$. pectinalis (Kutzing) Rabenhorst var. undulata (Ralfs) Rabh is replaced by E. pectinalis (Kutzing) Rabenhorst var. pectinalis Taf. In the Tuntang core G. gracilis Ehr. also increases. In the Dangkel core (Fig. 8) G. gracilis Ehr. is the most common dominant epiphyte and it cedes dominance to a diverse Eunotia flora. This transition is also evident in zone 2 of Tuntang core. On this basis, a reconstruction of $\mathrm{pH}$ of Zone II of Dangkel would suggest acidic conditions (less than $\mathrm{pH}$ 6) and to a lesser extent at Tuntang, with more neutral waters near Asinan.

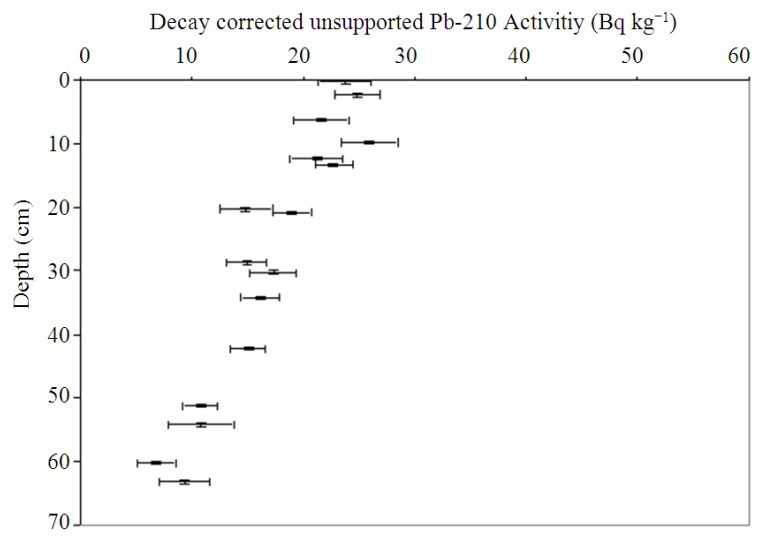

Fig. 2: Unsupported ${ }^{210} \mathrm{~Pb}$ versus depth of the Asinan core, trend of a decrease decay

Table 1: Sample numbers, depths, bulk densities, cumulative masses and count dates, total ${ }^{210} \mathrm{~Pb}$, supported ${ }^{210} \mathrm{~Pb}$, decay corrected unsupported ${ }^{210} \mathrm{~Pb}$, CIC and CRS models calculated ages and mass accumulation rates of Asinan core. Constant Mass of accumulation rate of CIC e.i., $1.15 \pm 0.11 \mathrm{~g} / \mathrm{cm}^{2} /$ year $\mathrm{R}^{2}=0.94$

\begin{tabular}{|c|c|c|c|c|c|c|c|c|c|}
\hline $\begin{array}{l}\text { Depth } \\
\text { sediment } \\
\text { sample } \\
(\mathrm{cm})\end{array}$ & $\begin{array}{l}\text { Dry bulk } \\
\text { density } \\
\left(\mathrm{g} / \mathrm{cm}^{3}\right)\end{array}$ & $\begin{array}{l}\text { Cumulative } \\
\text { dry mass } \\
\left(\mathrm{g} / \mathrm{cm}^{2}\right)\end{array}$ & Count date & $\begin{array}{l}\text { Total }{ }^{210} \mathrm{~Pb} \\
(\mathrm{mBq} / \mathrm{g}) \\
\text { or }(\mathrm{Bq} / \mathrm{kg})\end{array}$ & $\begin{array}{l}\text { Supported } \\
\mathrm{Pb}-210 \\
(\mathrm{mBq} / \mathrm{g}) \text { or } \\
(\mathrm{Bq} / \mathrm{kg})\end{array}$ & $\begin{array}{l}\text { Unsupported } \\
\text { Corrected } \\
\text { to reference } \\
\text { date } 15-\mathrm{Jan}-09 \\
(\mathrm{mBq} / \mathrm{g}) \text { or } \\
(\mathrm{Bq} / \mathrm{kg})\end{array}$ & $\begin{array}{l}\text { Calculated } \\
\text { CIC Ages } \\
\text { (years) }\end{array}$ & $\begin{array}{l}\text { Calculated } \\
\text { CRS Ages } \\
\text { (years) }\end{array}$ & $\begin{array}{l}\text { CRS model } \\
\text { Mass } \\
\text { Accumulation } \\
\text { Rates } \\
\mathrm{g} / \mathrm{cm}^{2} / \mathrm{y}\end{array}$ \\
\hline $0,0-0,5$ & 0,56 & $0,1 \pm 0,1$ & 20-Jan-09 & $48,0 \pm 1,6$ & $24,2 \pm 1,8$ & $23,7 \pm 2,4$ & $0,1 \pm 0,1$ & $0,1 \pm 0,2$ & $1,5 \pm 2,7$ \\
\hline $2,0-2,5$ & 0,90 & $1,6 \pm 0,2$ & 22-Mei-09 & $51,6 \pm 1,0$ & $27,0 \pm 1,7$ & $24,9 \pm 2,0$ & $1,4 \pm 0,2$ & $1,0 \pm 0,5$ & $1,5 \pm 0,7$ \\
\hline $6,0-6,5$ & 0,61 & $4,6 \pm 0,2$ & 20-Jan-09 & $43,6 \pm 1,9$ & $22,0 \pm 1,6$ & $21,6 \pm 2,5$ & $4,0 \pm 0,4$ & $3,0 \pm 0,8$ & $1,5 \pm 0,4$ \\
\hline $9,5-10,0$ & 1,34 & $8,0 \pm 0,2$ & 22-Mei-09 & $47,7 \pm 1,9$ & $22,1 \pm 1,6$ & $25,9 \pm 2,5$ & $7,0 \pm 0,7$ & $5,4 \pm 0,9$ & $1,5 \pm 0,3$ \\
\hline $13,0-13,5$ & 1,33 & $12,7 \pm 0,2$ & 22-Mei-09 & $42,9 \pm 1,1$ & $20,3 \pm 1,2$ & $22,8 \pm 1,7$ & $11,0 \pm 1,1$ & $9,2 \pm 1,0$ & $1,4 \pm 0,2$ \\
\hline $20,5-21,0$ & 0,69 & $20,3 \pm 0,2$ & 22-Mei-09 & $39,5 \pm 1,2$ & $20,7 \pm 1,3$ & $19,0 \pm 1,8$ & $17,6 \pm 1,7$ & $15,3 \pm 1,2$ & $1,3 \pm 0,1$ \\
\hline $28,5-29,0$ & 0,65 & $25,7 \pm 0,2$ & 22-Mei-09 & $37,0 \pm 1,1$ & $22,2 \pm 1,4$ & $15,0 \pm 1,8$ & $22,2 \pm 2,2$ & $19,4 \pm 1,3$ & $1,3 \pm 0,1$ \\
\hline $34,0-34,5$ & 0,70 & $29,4 \pm 0,2$ & 22-Mei-09 & $36,5 \pm 1,2$ & $20,6 \pm 1,3$ & $16,1 \pm 1,8$ & $25,5 \pm 2,5$ & $22,3 \pm 1,3$ & $1,3 \pm 0,1$ \\
\hline $42,0-42,5$ & 0,69 & $35,0 \pm 0,2$ & 22-Mei-09 & $32,3 \pm 0,9$ & $17,4 \pm 1,2$ & $15,1 \pm 1,5$ & $30,3 \pm 3,0$ & $27,3 \pm 1,4$ & $1,3 \pm 0,1$ \\
\hline $51,0-51,5$ & 0,92 & $42,2 \pm 0,2$ & 22-Mei-09 & $30,1 \pm 0,9$ & $19,5 \pm 1,3$ & $10,8 \pm 1,6$ & $36,6 \pm 3,6$ & $33,6 \pm 1,5$ & $1,3 \pm 0,1$ \\
\hline $54,0-54,5$ & 0,89 & $44,9 \pm 0,2$ & 20-Jan-09 & $37,8 \pm 2,1$ & $27,0 \pm 2,0$ & $10,8 \pm 2,9$ & $38,9 \pm 3,8$ & $35,8 \pm 1,5$ & $1,3 \pm 0,1$ \\
\hline $60,0-60,5$ & 1,39 & $51,8 \pm 0,2$ & 22-Mei-09 & $30,5 \pm 0,7$ & $23,8 \pm 1,5$ & $6,8 \pm 1,7$ & $44,8 \pm 4,4$ & $41,0 \pm 1,6$ & $1,26 \pm 0,05$ \\
\hline $63,0-63,5$ & 1,52 & $56,1 \pm 0,2$ & 20-Jan-09 & $36,9 \pm 1,2$ & $27,5 \pm 1,9$ & $9,4 \pm 2,3$ & $48,6 \pm 4,8$ & & \\
\hline
\end{tabular}


Am. J. Environ. Sci., 8(3): 334-344, 2012

Table 2: Sample numbers, depths, bulk densities, cumulative masses and count dates, total ${ }^{210} \mathrm{~Pb}$, supported ${ }^{210} \mathrm{~Pb}$, decay corrected unsupported $+\mathrm{Pb}$, CIC and CRS models calculated ages and mass accumulation rates of Tuntang. core. Constant Mass of accumulation rate of CIC e.i., $0.13 \pm 0.01 / \mathrm{cm}^{2} /$ year $\mathrm{R}^{2}=0.99$

\begin{tabular}{|c|c|c|c|c|c|c|c|c|c|}
\hline $\begin{array}{l}\text { ANSTO } \\
\text { ID } \\
\end{array}$ & $\begin{array}{l}\text { Depth } \\
(\mathrm{cm})\end{array}$ & $\begin{array}{c}\text { Dry Bulk } \\
\text { Density } \\
\left(\mathrm{g} / \mathrm{cm}^{3}\right) \\
\end{array}$ & $\begin{array}{l}\text { Cumulative } \\
\text { Dry Mass } \\
\left(\mathrm{g} / \mathrm{cm}^{2}\right)\end{array}$ & Count date & $\begin{array}{l}\text { Total Pb- } \\
{ }^{210}\left(\mathrm{mBq}^{-1}\right) \\
\text { or }(\mathrm{Bq} / \mathrm{kg})\end{array}$ & $\begin{array}{l}\text { Supported } \\
\mathrm{Pb}-210 \\
(\mathrm{mBq} / \mathrm{g} /) \text { or } \\
\left(\mathrm{Bq} / \mathrm{kg}^{1}\right)\end{array}$ & $\begin{array}{l}\text { Unsupported }{ }^{210} \mathrm{~Pb} \\
\text { Corrected } \\
\text { to reference } \\
\text { date } 12-\mathrm{Jan}-09 \\
(\mathrm{mBq} / \mathrm{g}) \text { or } \\
(\mathrm{Bq} / \mathrm{kg}) \\
\end{array}$ & $\begin{array}{l}\text { Calculated } \\
\text { CRS Ages } \\
\text { (years) }\end{array}$ & $\begin{array}{c}\text { CRS } \\
\text { model } \\
\text { Mass } \\
\text { Accumulation } \\
\text { Rates } \mathrm{g} / \mathrm{cm}^{2} / \mathrm{y}\end{array}$ \\
\hline L148 & $0.0-0.5$ & 0.47 & $0.1 \pm 0.1$ & 15-Jan-09 & $68.4 \pm 2.2$ & $15.1 \pm 1.2$ & $53.3 \pm 2.5$ & $0.2 \pm 0.3$ & $0.5 \pm 0.6$ \\
\hline L508 & $0.5-1.0$ & 0.73 & $0.4 \pm 0.1$ & 21-Jul-09 & $42.5 \pm 1.2$ & $6.7 \pm 1.1$ & $26.2 \pm 1.7$ & $0.9 \pm 0.4$ & $0.5 \pm 0.2$ \\
\hline L509 & $1.5-2.0$ & 1.01 & $1.3 \pm 0.2$ & 21-Jul-09 & $34.0 \pm 1.3$ & $19.5 \pm 1.5$ & $14.7 \pm 2.0$ & $1.9 \pm 0.6$ & $0.7 \pm 0.2$ \\
\hline L401 & $3.0-3.5$ & 0.64 & $2.5 \pm 0.2$ & 22-Мay-09 & $33.2 \pm 0.8$ & $17.0 \pm 1.1$ & $16.4 \pm 1.4$ & $3.0 \pm 0.7$ & $0.8 \pm 0.2$ \\
\hline L149 & $5.0-5.5$ & 0.59 & $3.8 \pm 0.2$ & 15-Jan-09 & $39.2 \pm 1.4$ & $13.6 \pm 1.1$ & $25.6 \pm 1.8$ & $4.6 \pm 0.8$ & $0.8 \pm 0.1$ \\
\hline L402 & $7.0-7.5$ & 0.60 & $4.9 \pm 0.2$ & 22-Мay-09 & $34.9 \pm 0.9$ & $13.6 \pm 1.1$ & $21.5 \pm 1.4$ & $6.4 \pm 0.9$ & $0.8 \pm 0.1$ \\
\hline L150 & $10.0-10.5$ & 0.63 & $6.8 \pm 0.2$ & 15-Jan-09 & $37.0 \pm 1.4$ & $23.7 \pm 1.7$ & $13.3 \pm 2.2$ & $8.6 \pm 1.0$ & $0.8 \pm 0.1$ \\
\hline L403 & $2.5-13.0$ & 0.79 & $8.6 \pm 0.2$ & 22-Мay-09 & $31.9 \pm 0.7$ & $17.5 \pm 1.1$ & $14.5 \pm 1.4$ & $10.5 \pm 1.1$ & $0.8 \pm 0.1$ \\
\hline L151 & $15.0-15.5$ & 0.74 & $10.5 \pm 0.2$ & 15-Jan-09 & $37.2 \pm 1.3$ & $22.5 \pm 1.6$ & $14.8 \pm 2.1$ & $12.7 \pm 1.1$ & $0.8 \pm 0.1$ \\
\hline L404 & $17.5-18.0$ & 0.66 & $12.2 \pm 0.2$ & 22-Мay-09 & $31.0 \pm 0.9$ & $15.4 \pm 1.0$ & $15.8 \pm 1.3$ & $15.0 \pm 1.2$ & $0.8 \pm 0.1$ \\
\hline L405 & $27.5-28.0$ & 0.86 & $19.8 \pm 0.2$ & 22-Мay-09 & $23.8 \pm 0.7$ & $12.7 \pm 0.9$ & $11.2 \pm 1.1$ & $25.4 \pm 1.4$ & $0.8 \pm 0.1$ \\
\hline L406 & $33.5-33.5$ & 0.54 & $23.9 \pm 0.2$ & 22-Мay-09 & $24.4 \pm 1.0$ & $12.2 \pm 0.8$ & $12.3 \pm 1.3$ & & \\
\hline
\end{tabular}

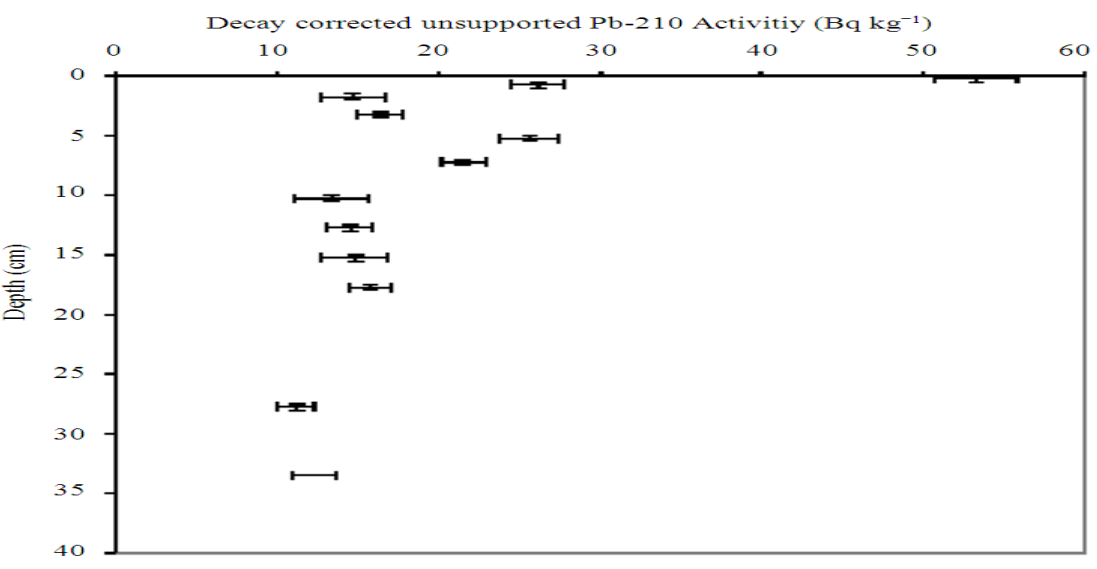

Fig. 3: Unsupported ${ }^{210} \mathrm{~Pb}$ versus depth to the Tuntang core

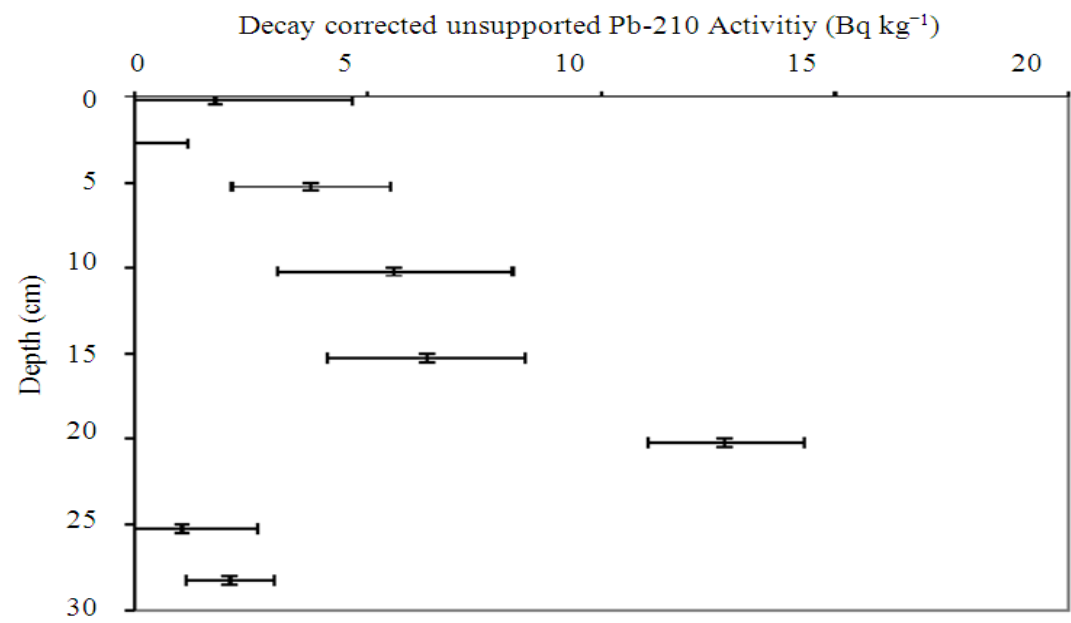

Fig. 4: Unsupported ${ }^{210} \mathrm{~Pb}$ versus depth for the Dangkel core 
Am. J. Environ. Sci., 8 (3): 334-344, 2012

Table 3: Sample numbers, depths, bulk densities, cumulative masses and count dates, total ${ }^{210} \mathrm{~Pb}$, supported ${ }^{210} \mathrm{~Pb}$, decay corrected unsupported ${ }^{11} \mathrm{~Pb}$ of Dangkel core

\begin{tabular}{|c|c|c|c|c|c|c|}
\hline $\begin{array}{l}\text { Depth } \\
\text { sediment } \\
\text { samples } \\
(\mathrm{cm})\end{array}$ & $\begin{array}{l}\text { Dry Bulk } \\
\text { Density } \\
\left(\mathrm{g} / \mathrm{cm}^{3}\right)\end{array}$ & $\begin{array}{l}\text { Cumulative } \\
\text { Dry mass } \\
\left(\mathrm{g} / \mathrm{cm}^{2}\right)\end{array}$ & $\begin{array}{l}\text { Total } \mathrm{Pb}-210 \\
\text { Count } \\
\text { Date }\end{array}$ & $\begin{array}{l}\mathrm{Pb}-210 \\
(\mathrm{mB} / \mathrm{q} / \mathrm{g}) \\
\text { or }(\mathrm{Bq} / \mathrm{kg})\end{array}$ & $\begin{array}{l}\text { Supported } \\
\text { to reference } \\
(\mathrm{mBq} / \mathrm{g}) \\
\text { or }(\mathrm{Bq} / \mathrm{kg})\end{array}$ & $\begin{array}{l}\text { Unsupported } 210 \\
\mathrm{~Pb} \text { corrected } \\
\text { date } 12-\mathrm{Jan}-09 \\
(\mathrm{mBq} / \mathrm{g}) \text { or }(\mathrm{Bq} / \mathrm{kg})\end{array}$ \\
\hline $0,0-0,5$ & 0,13 & $0,03 \pm 0,03$ & 16-Jan-0909 & \multirow{8}{*}{\multicolumn{3}{|c|}{ Activities of Po-210 and Ra-226were below detectable limits }} \\
\hline $2,5-3,0$ & 0,16 & $0,40 \pm 0,04$ & 16-Jan-09 & & & \\
\hline $5,0-5,5$ & 0,12 & $0,75 \pm 0,04$ & 16-Jan-09 & & & \\
\hline $10,0-10,5$ & 0,14 & $1,40 \pm 0,03$ & 16-Jan-09 & & & \\
\hline $15,0-15,5$ & 0,14 & $2,09 \pm 0,03$ & 16-Jan-09 & & & \\
\hline $20,0-20,5$ & 0,19 & $2,89 \pm 0,04$ & 16-Jan-09 & & & \\
\hline $25,0-25,5$ & 0,14 & $3,71 \pm 0,04$ & 16-Jan-09 & & & \\
\hline $28,0-28,5$ & 0,90 & $5,27 \pm 0,05$ & 16-Jan-09 & & & \\
\hline
\end{tabular}

Table 4: Sample numbers, depths, bulk densities, cumulative masses and count dates, total ${ }^{210} \mathrm{~Pb}$, supported ${ }^{210} \mathrm{~Pb}$, decay corrected unsupported ${ }^{210} \mathrm{~Pb}$, CIC and CRS models calculated ages and mass accumulation rates of Panjang core. Constant Mass accumulation rate of CIC e.i. $1.309 \pm 0.01 \mathrm{~g} \mathrm{~cm}^{-2} /$ year $\mathrm{R}^{2}=0.6039$

\begin{tabular}{|c|c|c|c|c|c|c|c|c|c|}
\hline $\begin{array}{l}\text { Depth } \\
\text { sediment } \\
\text { samples } \\
(\mathrm{cm})\end{array}$ & $\begin{array}{l}\text { Dry bulk } \\
\text { density } \\
\left(\mathrm{g} / \mathrm{cm}^{3}\right)\end{array}$ & $\begin{array}{l}\text { Cumulative } \\
\text { dry mass } \\
(\mathrm{g} / \mathrm{cm})\end{array}$ & $\begin{array}{l}\text { Count } \\
\text { date }\end{array}$ & $\begin{array}{l}\text { Total Pb-210 } \\
(\mathrm{Bq} / \mathrm{kg}) \\
\text { or }\left(\mathrm{Bq} \mathrm{kg}{ }^{-1}\right)\end{array}$ & $\begin{array}{l}\text { Supported } \\
\mathrm{Pb}-210 \\
\mathrm{mBq} / \mathrm{g}) \\
\text { or }(\mathrm{mBq} / \mathrm{g})\end{array}$ & $\begin{array}{l}\text { Unsupported } \\
{ }^{210} \mathrm{~Pb} \text { corrected } \\
\text { to reference } \\
12-\mathrm{Jan}-09 \\
(\mathrm{mBq} / \mathrm{g}) \\
\text { or }(\mathrm{Bq} / \mathrm{kg})\end{array}$ & $\begin{array}{l}\text { date } \\
\text { Calculated } \\
\text { CRS ages } \\
\text { (years) }\end{array}$ & $\begin{array}{l}\text { Calculated } \\
\text { CIC ages } \\
\text { (years) }\end{array}$ & $\begin{array}{l}\text { CRS model mass } \\
\text { accumulation } \\
\text { rates } \\
\mathrm{g} / \mathrm{cm}^{2} / \mathrm{y}\end{array}$ \\
\hline $0,0-0,5$ & 1,00 & $0,3 \pm 0,3$ & 15-Jan-09 & $38,1 \pm 1,3$ & $23,9 \pm 1,6$ & $14,2 \pm 2,1$ & $0,19 \pm 0,22$ & $0,16 \pm 0,39$ & $1,55 \pm 3,74$ \\
\hline $5,0-5,5$ & 1,00 & $5,3 \pm 0,3$ & 15-Jan-09 & $40,4 \pm 1,3$ & $23,8 \pm 1,6$ & $16,6 \pm 2,1$ & $4,01 \pm 2,31$ & $3,68 \pm 1,72$ & $1,43 \pm 0,67$ \\
\hline $10,0-10,5$ & 1,00 & $10,3 \pm 0,3$ & 15-Jan-09 & $36,2 \pm 1,0$ & $25,1 \pm 1,8$ & $11,1 \pm 2,0$ & $7,83 \pm 4,49$ & $7,16 \pm 2,02$ & $1,43 \pm 0,40$ \\
\hline $16,0-16,5$ & 1,00 & $16,3 \pm 0,3$ & 15-Jan-09 & $33,4 \pm 0,9$ & $22,7 \pm 1,7$ & $10,7 \pm 1,9$ & $12,42 \pm 7,11$ & $10,89 \pm 2,30$ & $1,49 \pm 0,32$ \\
\hline
\end{tabular}

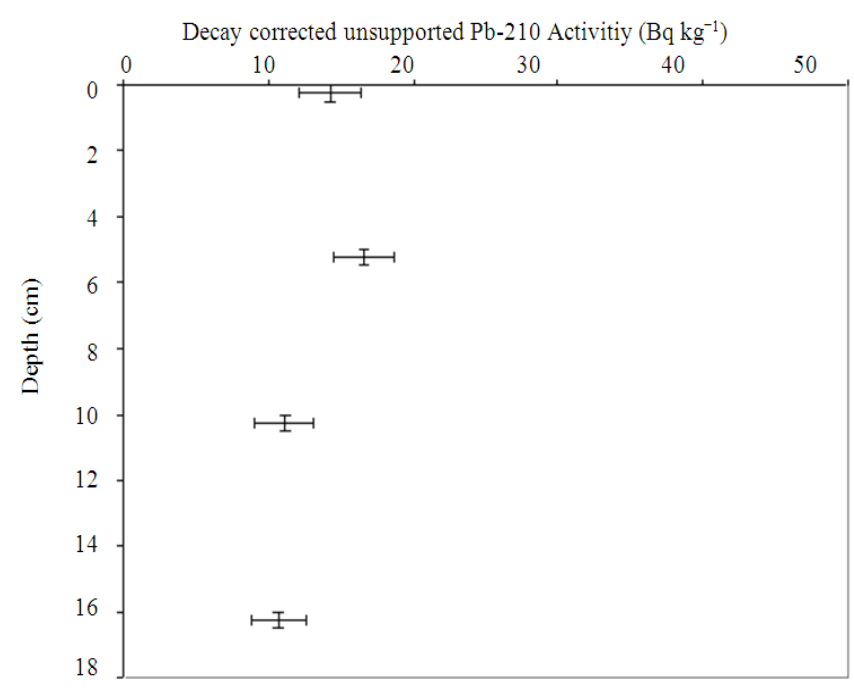

Fig. 5: Unsupported ${ }^{210} \mathrm{~Pb}$ versus depth Panjang core

Zone II (1984-1990): In Zone II of Asinan, eucentric diatoms (Aulacoseira spp.) increase at the expense of all others, except for S. ulna (Nitzsch) Ehrenberg. While A. granulata (Ehrenberg) Simonsen is considered a mesoeutrophic species, D. stelligera (Cleve and Grunow) Houk and Klee and A. distans (Ehrenberg) Simonsen are more common in oligotrophic, clear waters. This transition to plankton is accompanied by the decline in benthic and epiphytic taxa. The transition to plankton is marked by D. stelligera (Cleve and Grunow) Houk and Klee and $A$. distans (Ehrenberg) Simonsen at Tuntang also, but not at Panjang or Dangkel. The rise in $A$. granulata (Ehrenberg) Simonsen is common to all four cores but the chronology would suggest this timing of this change varies.

Zone I (1990-2008): This upper zone in Asinan is dominated by $A$. ambigua (Grunow) Simonsen, $A$. granulata (Ehrenberg) Simonsen and U. acus (Kutzing) M. Aboel. The abundance of A. distans (Ehrenberg) Simonsen is lower here than Zone II and D. stelligera (Cleve and Grunow) Houk and Klee decreases through this zone to the surface. Within this zone $U$. acus (Kutzing) M.Aboel. is common, but declines sharply at 339 
$5 \mathrm{~cm}$ with a synchronous increase in A. ambigua (Grunow) Simonsen. This increase in Aulacoseira spp. is also evident in Dangkel (at $11 \mathrm{~cm}$ or c. 1990 AD in that core) and in Tuntang, where the rise in A. ambigua (Grunow) Simonsen is less marked. In Panjang $A$. ambigua (Grunow) Simonsen is common throughout but increases after $2001 \mathrm{AD}$, but $A$. granulata (Ehrenberg) Simonsen is less common after 1986 AD. Despite this, the shift to an Aulacoseira-dominated plankton is a lake-wide shift.

Zone II (1984-1990): In Zone II of Asinan, eucentric diatoms (Aulacoseira spp.) increase at the expense of all others, except for $S$. ulna (Nitzsch) Ehrenberg. While $A$. granulata (Ehrenberg) Simonsen is considered a mesoeutrophic species, D. stelligera (Cleve and Grunow) Houk and Klee and A. distans (Ehrenberg) Simonsen are more common in oligotrophic, clear waters. This transition to plankton is accompanied by the decline in benthic and epiphytic taxa. The transition to plankton is marked by D. stelligera (Cleve and Grunow) Houk and Klee and $A$. distans (Ehrenberg) Simonsen at Tuntang also, but not at Panjang or Dangkel. The rise in $A$. granulata (Ehrenberg) Simonsen is common to all four cores but the chronology would suggest this timing of this change varies.

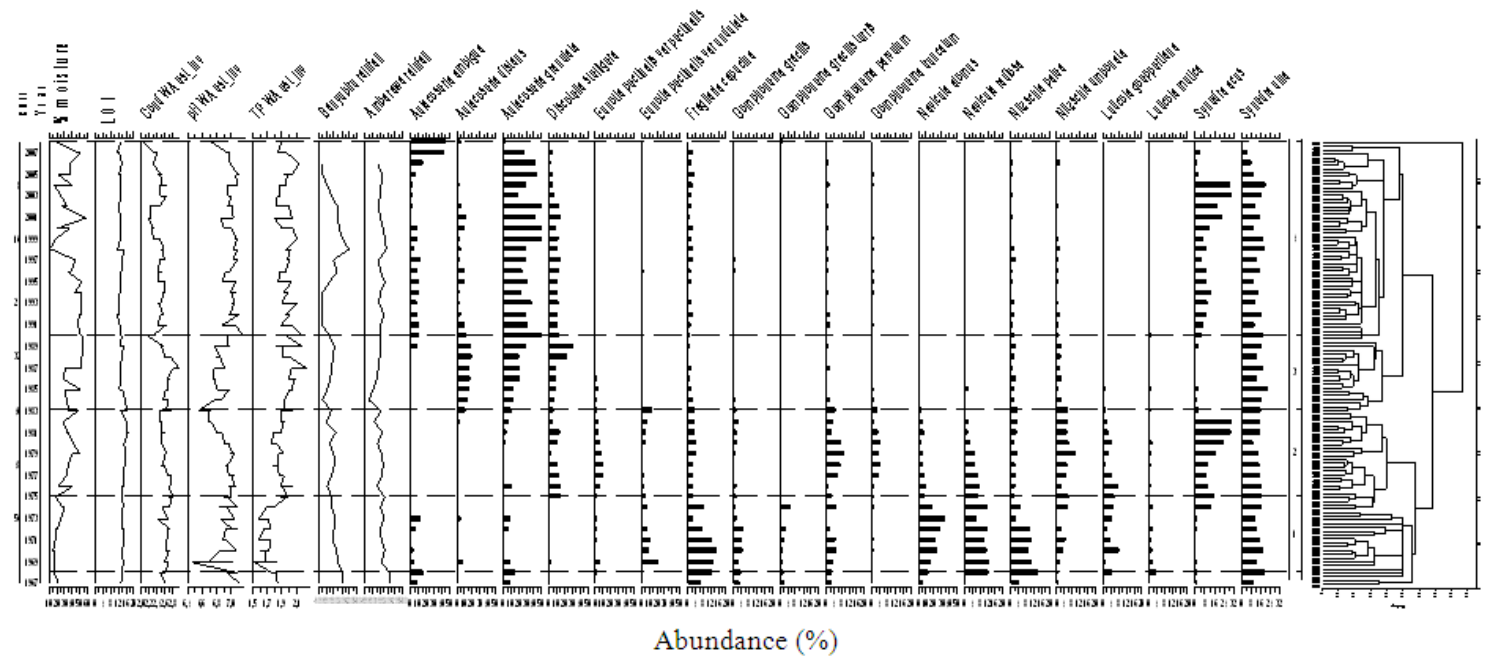

Fig. 6: Stratigraphic estimation of cores'year, moisture, LOI, reconstruction of conductivity, $\mathrm{pH}$ and TP, rainfall, diatom species, zonation and cluster of Asinan core, Rawapening Lake

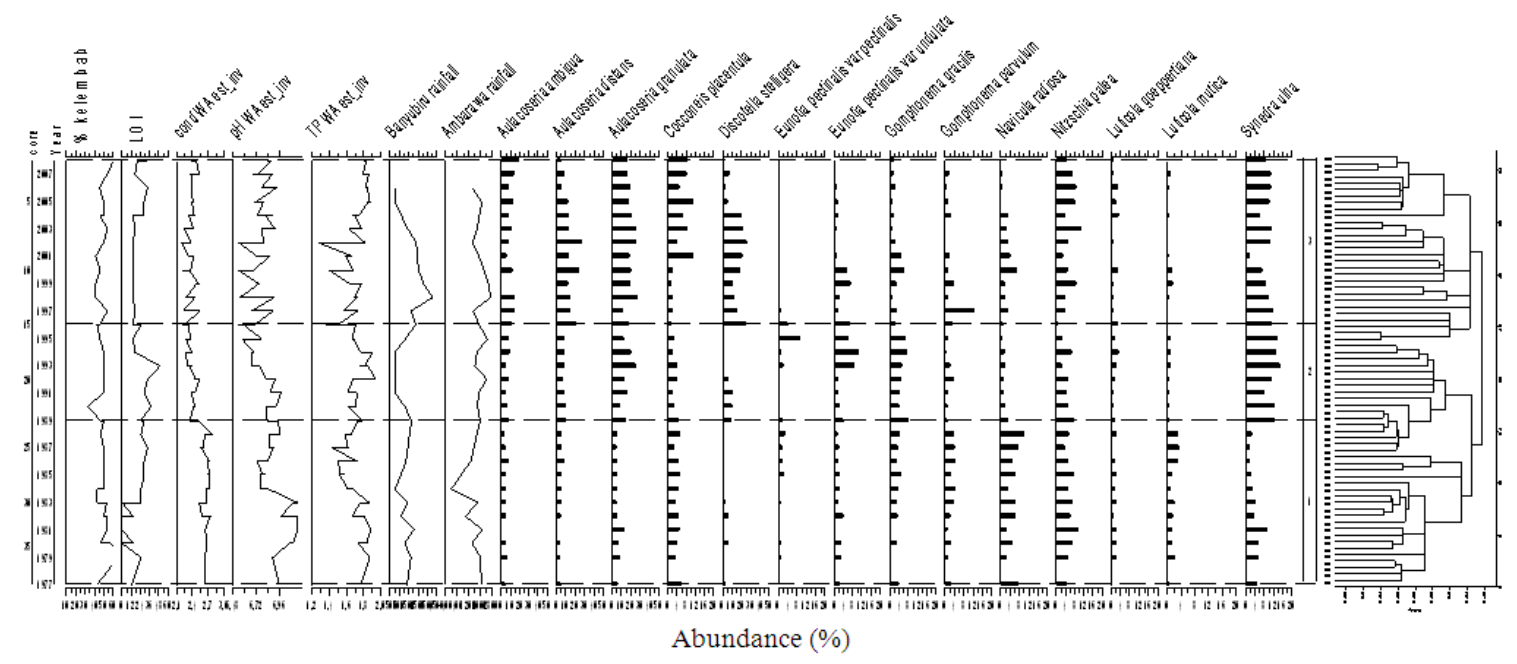

Fig. 7: Stratigraphic estimation of cores'year, moisture, LOI, reconstruction of conductivity, $\mathrm{pH}$ and TP, rainfall, diatom species, zonation and cluster of Tuntang core, Rawapening Lake 


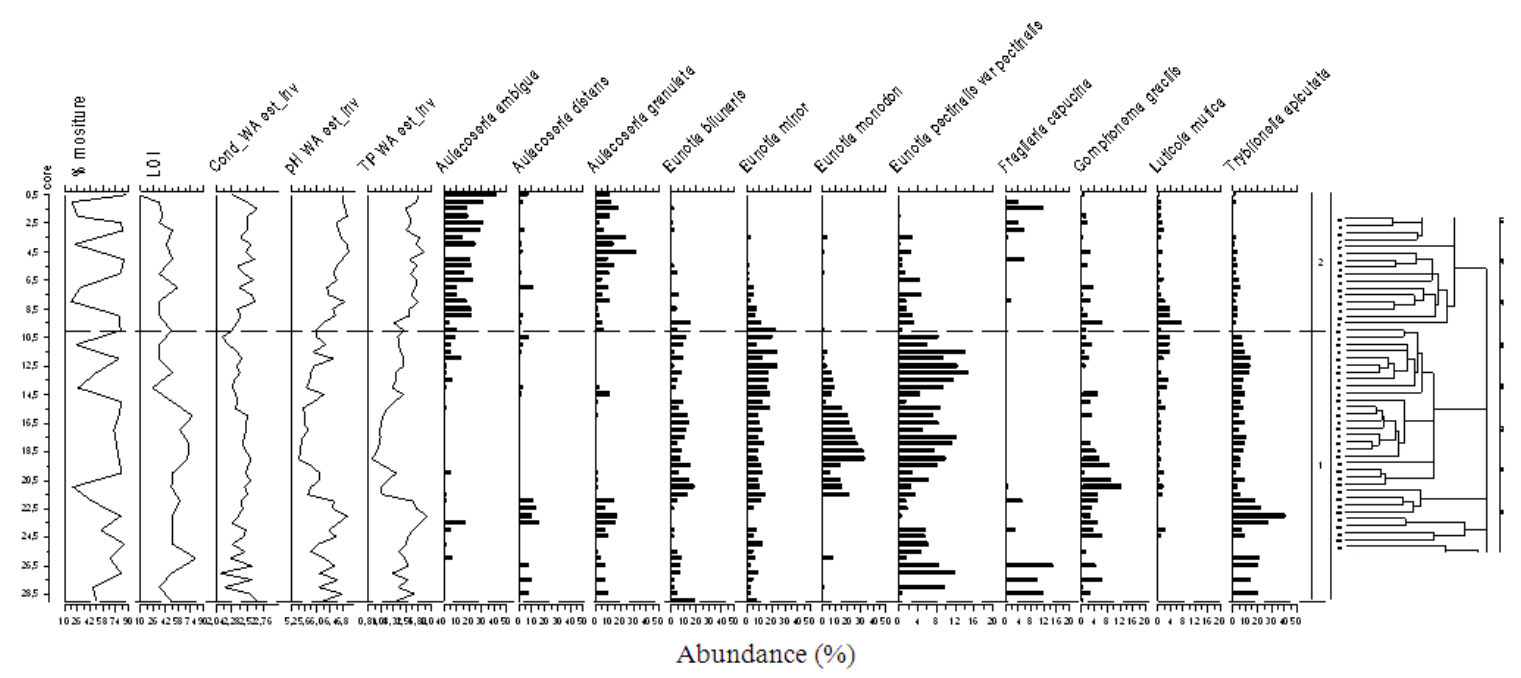

Fig. 8: Stratigraphic estimation of cores'year, moisture, LOI, reconstruction of conductivity, pH and TP, rainfall, diatom species, zonation and cluster of Dangkel core, Rawapening Lake

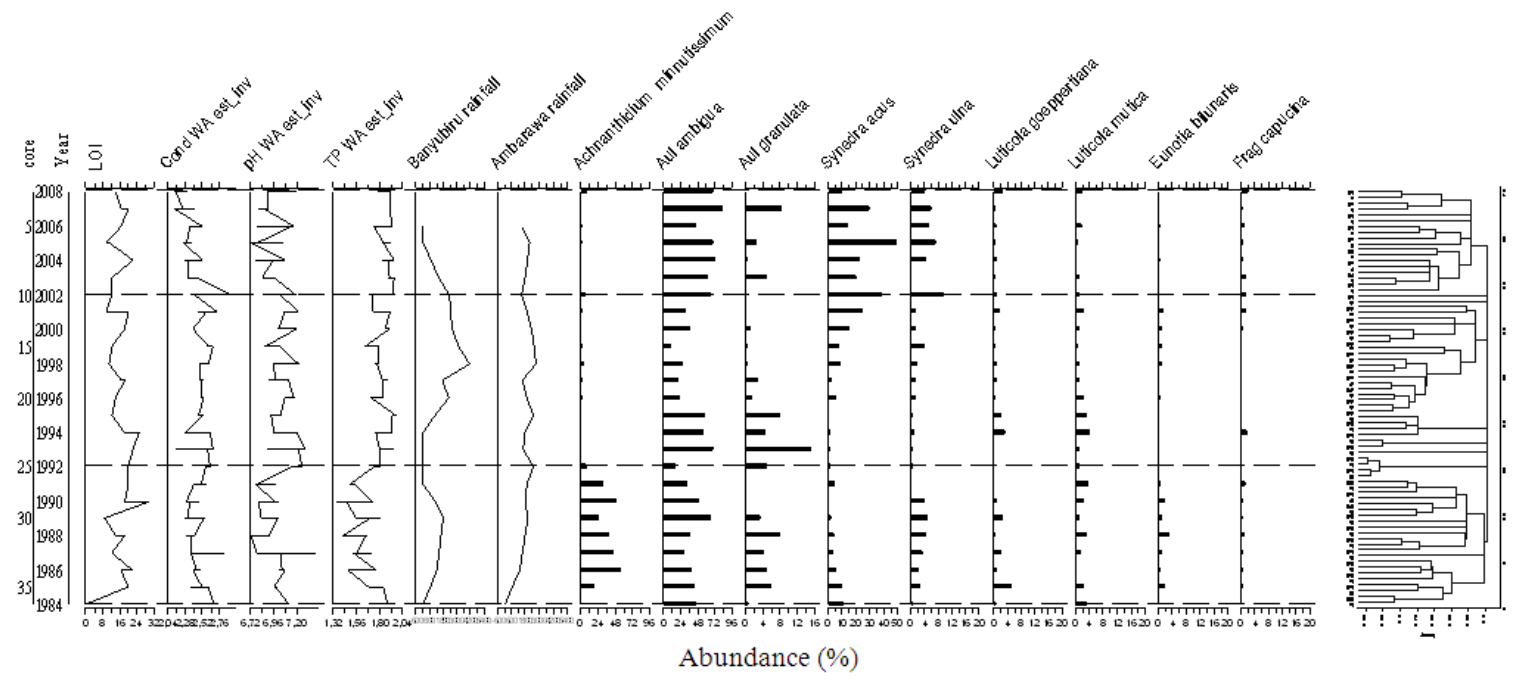

Fig. 9: Stratigraphic estimation of cores'year, moisture, LOI, reconstruction of conductivity, $\mathrm{pH}$ and TP, rainfall, diatom species, zonation and cluster of Panjang core, Rawapening Lake

Zone I (1990-2008): This upper zone in Asinan is dominated by $A$. ambigua (Grunow) Simonsen, $A$. granulata (Ehrenberg) Simonsen and U. acus (Kutzing) M.Aboel. The abundance of A. distans (Ehrenberg) Simonsen is lower here than Zone II and D. stelligera (Cleve and Grunow) Houk and Klee decreases through this zone to the surface. Within this zone $U$. acus (Kutzing) M.Aboel. is common, but declines sharply at $5 \mathrm{~cm}$ with a synchronous increase in A. ambigua (Grunow) Simonsen. This increase in Aulacoseira spp. is also evident in Dangkel (at $11 \mathrm{~cm}$ or c. 1990 AD in that core) and in Tuntang, where the rise in A. ambigua
(Grunow) Simonsen is less marked. In Panjang $A$. ambigua (Grunow) Simonsen is common throughout but increases after $2001 \mathrm{AD}$, but $A$. granulata (Ehrenberg) Simonsen is less common after 1986 AD. Despite this, the shift to an Aulacoseira-dominated plankton is a lake-wide shift.

\section{DISCUSSION}

The ${ }^{210} \mathrm{~Pb}$ age of the sediment cores indicates that the basal sediment of Rawapening Lake is less than 100 years old. The Constant Initial Concentration (CIC) and 
Constant Rate of Supply (CRS) ${ }^{210} \mathrm{~Pb}$ dating model used to calculate sediment ages compared well. Both models assume constant flux of unsupported ${ }^{210} \mathrm{~Pb}$ at the sediment-water interface. The basic assumption of the CRS model is that the rate of supply of fallout ${ }^{210} \mathrm{~Pb}$ to the core site is constant, reflecting the constant flux of ${ }^{210} \mathrm{~Pb}$ from the atmosphere. The CIC (constant initial ${ }^{210} \mathrm{~Pb}$ concentration) model assumes that sediments in the core all had the same initial unsupported ${ }^{210} \mathrm{~Pb}$ concentration at the time they were laid down on the bed of the lake, regardless of differences in the sedimentation rate (Walling et al., 2003). For all four cores from Rawapening, the CRS model performed better than the CIC model, since the CRS model accounts for any variations in sedimentation rates over time, while the CIC model assumes a constant sedimentation rate for the period of time over which unsupported ${ }^{210} \mathrm{~Pb}$ exhibits a decay profile.

The longest sediment core was from Asinan (63 $\mathrm{cm})$, possibly related to the lowest erosion rate (40.18 ton/Ha) from the nearby catchment. The catchment areas near Panjang and Tuntang have middle-heavy erosion rates of 73.37-303.75 ton/ $\mathrm{Ha}$ and 17.84-78.7 ton/Ha, respectively (GS, 2000).

Eucentric diatoms dominated (up to 70\%) the modern flora of Rawapening Lake, consistent with the major influence of inlets/rivers (Asinan and Panjang). Meanwhile, in the centre of the lake, eucentric diatoms still dominated but in lower percentages (30\% in Tuntang and $40 \%$ in Dangkel). Most of eucentric diatoms are planktonic, but are commonly found in the sediment (Sonneman, 1999; Soeprobowati et al., 2001).

The predominance of Synedra from 1967 to present indicates that Rawapening Lake has been fresh and meso-eutrophic throughout. Synedra ulna (Nitzsch) Ehrenberg is a tolerant species, found in the Indonesian rivers and lakes with high organic content and so a total phosphorous content of $20-1,000 \mu \mathrm{g} \mathrm{L}^{-1}$ and $\mathrm{pH}$ of 5- 9 can be inferred from local records. The modern sampling of $\mathrm{pH}$ at Rawapening reveals it to fluctuate widely. Research in 1976 (Goltenboth, 1979) reported the $\mathrm{pH}$ of Rawapening Lake was 7.2-7.6. EPA-ERC Undip (1999), reported that the $\mathrm{pH}$ of Rawapening Lake was alkaline (7.5-8.8). In 2004 and 2005 , the $\mathrm{pH}$ of the inlet and lake tended to neutral, except in the site around the spring and floating island where the pH was 9.52 (Soeprobowati et al., 2005). During field work for this study (2008), Rawapening had a $\mathrm{pH}$ of more than 11 . Zone 1 , the upper diatom zone in the lake sediments, was dominated by Aulacoseira ambigua (Grunow) Simonsen, A. granulata (Ehrenberg) Simonsen and $U$. acus (Kutzing) M.Aboel. This indicates that, from 1990 to present, Rawapening pH varied from 6.5-9.
The deepest section of the Rawapening sediment sequence is dominated by mostly periphytic species, widely known to prefer eutrophic to hyper eutrophic conditions. For example, Nitzschia palea (Kutzing) W. Smith is epipelic or epiphitic diatom that is widely distributed in eutrophic waters (Dam et al., 1994; Gell, 1999; Gell et al., 2007; Soeprobowati et al., 2001; 2005). This is accompanied, or followed by, an increase in epiphytes Gomphonema spp. Prefer circumneutral to alkaline conditions while Eunotia spp. Tend to exist in circumneutral in acid waters. This site variation may reflect the variable accumulation of organic matter from dead macrophytes that would locally reduce $\mathrm{pH}$, at least periodically. The transition from Gomphonema spp. to Eunotia spp. supports this notion of an increase in macrophyte cover (epiphytic diatoms) that induces more acidic waters suited to acidophilous taxa.

The most marked shift in the Rawapening sediment sequence is the transition to euplanktonic diatoms at the expense of benthic and epiphytic taxa at c. 1983 AD. Initially this transition was marked by increases in $A$. granulata (Ehrenberg) Simonsen, but also D. stelligera (Cleve and Grunow) Houk and Klee and A. distans (Ehrenberg) Simonsen. Such a shift to phytoplankton in eutrophic lakes is often stimulated by a reduction in the euphotic zone, possibly by an increase in the supply of clay and colloidal sediments. While the dating does not reveal changing sedimentation rates, increased human activity in the catchment may have lead to an increased flux in fine sediment that can remain in suspension impacting on the light regime. Such a state switch can occur independent of increases in total nutrient concentrations (Scheffer 1990; Scheffer et al., 1993) and this appears to be the case with basal core sediments supporting taxa with preferences for eutrophic waters. Typically, where the euphotic depth shallows, aquatic plants attached to the substrate decline and nutrients and sediments are further releases into the water column. This drive increases in phytoplankton which can continue to exploit the light that is confined to the surface waters (Reid et al., 2007). This sequence is evident in the diatom record from the Rawapening sediments that has ultimately come to be dominated by planktonic forms that are able to thrive in eutrophic, turbid and alkaline waters.

The reconstruction of nutrients, particularly of total phosphorus, was undertaken using a European data set. The diatom inferred total phosphorous concentration from the upper zone of the Asinan core was 20-200 $\mu \mathrm{g}$ $\mathrm{L}^{-1}$ ). This range appears likely, given the evidence for its eutrophic state (Sonneman, 1999) from modern sampling. The poor representation of fossil taxa in the European data set has precluded a more robust reconstruction. Indonesia does not have yet an extensive diatom data set of nutrient or $\mathrm{pH}$ 
reconstruction. Despite this, the European based reconstructions performed well, such as evidence for fluctuating $\mathrm{pH}$.

Nevertheless, the development of Indonesian data set is essential to provide a data set of tropical diatoms that are local to the region. Its implementation will provide more accurate reconstructions compared to those attempted using a data set from another continent and climate zone.

It was predicted that Rawapening Lake would be filled with sediment (GS, 2000) as early as 2021, based on the remote sensing data (1972-2009) of land use changes in the catchment area of Rawapening Lake. This documented a decrease in the extent of paddy field plantations and crop dry land, followed by an increase in settlement. In 2009 the percentage of settlement was $19.03 \%$ of land and it is forecast to be $32.78 \%$ in 2099 . The sedimentation rates suggest that a high percentage of Rawapening Lake remains stable. It indicates that the shallowing and sedimentation of the lake has not greatly reduced the lake as predictions would suggest, although the lake volume continues to decrease.

Co-management had been implemented in Rawapening (RCNDP UGM, 2000). The 2005-2010 action plan of Rawapening Development (CJPB, 2005) has been implemented to conserve Rawapening Lake, but its condition remains far from expectations due to a limited commitment to restoration. The record of change from lake sediments attests to a long history of elevated nutrient concentrations, but a shift to a less productive state from the 1980s through sediment input. Stakeholders, public and government bodies alike, have to be more integrated in the implementation of a program of co-management of the lake and catchment. Integrated and sustainable lake management needs to be developed, preferably based on the reconstructed past ecological condition using modern and fossil diatom assemblages, to understand trajectories and drivers of change, to predict changes in the future and the means to arrest state decline.

\section{CONCLUSION}

The condition of Rawapening Lake may be divided into 4 zones: zone 4 (1967-1974), zone 3 (1974-1983), zone 2 (1984-1990) and zone 1 (1990-2008). The dominance of benthic indicators of high nutrient status reveals that Rawapening has a long history of eutrophication. A rise in epiphytic and acidiphilous taxa suggests that high nutrients encouraged aquatic macrophytes that may have periodically caused reductions in $\mathrm{pH}$. The abrupt change to euplanktonic taxa in the 1980s documents a state shift that passed initially though relatively clear water conditions, but with a limited photic depth that reduced attached plants, to a turbid phytoplankton-dominated system. Rather than being linked to increased nutrients, this change is most likely driven by an increased flux of fine sediments that continue to advantage a food web based on phytoplankton rather that aquatic macrophytes.

\section{ACKNOWLEDGMENT}

This project is supported by Indonesian Higher Education through Fundamental Research Grant Number: 321/SP2H/PP/DP3M/III/2008, DIPA UGM Budget Contract Number: LPPM-UGM/1177/2009, Australian Institute of Nuclear Science and Engineering (AINSE) Grant 09065 for ${ }^{210} \mathrm{~Pb}$ dating. Thanks to Keely Mills and Rosie Grundell from The University of Ballarat, Australia for helping in diatom analysis, Jafron Wasiq Hidayat and Kariyadi Baskoro Diponegoro University Semarang Indonesia for helping in field work and Nina Desianti from Oklahoma University US for her helping on data analysis.

\section{REFERENCES}

CJPB, 2005. Penyusunan Action Plan Pengembangan Kawasan Rawapening. 1st Edn., Laporan Akhir, CV., Galihloka Semarang, pp: 136.

Dam, H.V., A. Mertens and J. Sinkeldam, 1994. A coded checklist and ecological indicator values of freshwater diatoms from the Netherlands. Netherlands J. Aquatic Ecol., 28: 117-133. DOI: $10.1007 / \mathrm{BF} 02334251$

Dixit, S.S., W.B. Keller, A.B Dixit and J.P. Smol, 2001. Diatom-inferred dissolved organic carbon reconstructions provide assessments of past UV-B penetration in Canadian Shield lakes. Can. J. Fish. Aquat. Sci., 58: 543-550.

EM, 2010. 2010-2014 National Lake Priority Program. 1st Edn., Environment Ministry, Kementerian Lingkungan Hidup, pp: 7.

EPA-ERC Undip, 1999. Environmental Quality Index Development and Biological Indicator. 1st Edn., Research Institute Diponegoro University, Semarang, pp: 81.

Gell, P., J. Tibby, F. Little, D. Baldwin and G. Hancock, 2007. The impact of regulation and salinisation on floodplain lakes: The lower River Murray, Australia. Hydrobiologia, 591: 135-146. DOI: 10.1007/s10750-007-0806-3

Gell, P.A., 1999. An Illustrated Key to Common Diatom Genera from Southern Australia. 1st Edn., CRC for Freshwater Ecology, Thurgoona, NSW, ISBN-10: 1876144270, pp: 63. 
Goltenboth, F. and K.H. Timotius, 1994. Danau Rawapening di Jawa Tengah, Indonesia. 1st Edn., Satya Wacana University Press, Salatiga, pp: 68.

Goltenboth, F., 1979. Preliminary Final Report. 1st Edn., Satya Wacana Christian University, Salatiga, pp: 54.

GS, 2000. Proyek Perencanaan Tata Lingkungan Daerah Aliran Sungai (DAS) Rawapening. 1st Edn., Government of Semarang, PT, Comarindo Mahameru, Semarang, pp: 119.

Hehanusa, P.E. and G.S.D. Haryani, 2009. Classification of Indonesian lake morphogenesis for climate change mitigation (Klasifikasi morfogenesis Danau DI Indonesia untuk mitigasi dampak perubahan iklim). Makalah disampaikan dalam Konferensi Nasional Danau Indonesia I, Sanur-Denpasar-Bali.

Juggins, S., 2001. The European diatom database. University of Newcastle.

Juggins, S., 2003. Software for ecological and palaeoecological data analysis and visualization. University of Newcastle.

Krammer, K. and H. Lange-Bertalot, 2010. Susswasserflora von Mitteleuropa, Bd. 2/1: Bacillariophyceae, Teil 1: Naviculaceae. 1st Edn., Spektrum Akademischer Verlag, ISBN-10: 3827426154, pp: 882.

Last, W.M. and J.P. Smol, 2001. Tracking Environmental Change is using Lake Sediments. 1st Edn., Springer, Boston, ISBN-10: 0792364821, pp: 548.

Mann, D.G. 1999. The species concept in diatoms. Phycologia, 38: 437-495. DOI: 10.2216/i00318884-38-6-437.1

Reid, M.A. R.W. Ogen, 2009. Factor affecting diatom distribution in floodplain lakes of the Southeast Murray basin, Australia and implications for paleolimnological studies. J. Paleol., 41: 453-470. DOI: $10.1007 / \mathrm{s} 10933-008-9236-0$

Reid, M.A., C. Tibby, D. Penny and P.A. Gell, 1995. The use of diatoms to assess past and present water quality. Aust. J. Ecol.., 20: 57-64. DOI: 10.1111/j.1442-9993.1995.tb00522.x
Reid, M.A., C.D. Sayer, A.P.Kershaw and H. Heijnis, 2007. Palaeolimnological evidence for submerged plant loss in a floodplain lake associated with accelerated catchment soil erosion (Murray River, Australia). J. Paleol., 38: 191-208. DOI: $10.1007 /$ s10933-006-9067-9

Scheffer, M., 1990. Multiplicity of stable states in freshwater systems. Hydrobiologia, 201: 475-486. DOI: $10.1007 / \mathrm{BF} 02530365$

Scheffer, M., S.H. Hosper, M.L. Meijer, B. Moss and E. Jeppesen, 1993. Alternative equilibria in shallow lakes. Trends Ecol. Evolution, 8: 275-279. DOI: 10.1016/0169-5347 (93)90254-M

Smol, J.P., 2008. Pollution of Lakes and Rivers: A Paleoenvironmental Perspective. 2nd Edn., WileyBlackwell, USA., ISBN-10: 1405159138, pp: 396.

Soeprobowati, T.R., H. Sugondo, I.B. Hendrarto, I. Sumantri and B. Toha, 2001. Diatom and Ecological Changes of the River. Universitas Satya Wacana, Salatiga.

Soeprobowati, T.R., W.A. Rahmanto, J.W. Hidayat and K. Baskoro, 2005. Diatoms and present condition of Rawapening Lake. Int. Seminar Environ. Chem. Toxi.

Sonneman, J.A., 1999. An Illustrated Guide to Common Stream Diatom Species from Temperate Australia. 1st Edn., Cooperative Research Centre for Freshwater Ecology, Albury, ISBN-10: 1876144351 , pp: 166.

UNEP, 1999. Technology Needs for Lake Management in Indonesia: Case Studies, Lakes Rawa Danau and Rawa Pening, Java. 1st Edn., UNEP International Environmental Technology Centre, Osaka, Japan, pp: 127.

Walling, D.E., Q. He and P.G. Appleby, 2003. Conversion models for use in soil-erosion, soilredistribution and sedimentation investigations. Handbook Assess. Soil Erosion Sediment Environ. Radionuclides, 111-164. DOI: 10.1007/0-30648054-9_7 